\title{
APLIKASI KALSIUM KLORIDA DAN ETHEPHON DALAM UPAYA PENINGKATAN KUALITAS BUAH NANAS (Ananas comosus (L) Merr)
}

\section{APPLICATION AND ETHEPHON OF CALCIUM CHLORIDE FOR IMPROVING THE FRUIT QUALITY OF PINEAPPLE}

\author{
Nungki Kusuma Astuti', Moch. Dawam Maghfoer ${ }^{2)}$ dan Roedy Soelistyono ${ }^{2)}$ \\ ${ }^{1)}$ Mahasiswa Pascasarjana Program Studi Ilmu TanamanFakultas Pertanian Universitas Brawijaya, \\ Jalan Veteran, Malang 65145 \\ ${ }^{2)}$ Fakultas Pertanian Universitas Brawijaya, Jalan Veteran, Malang 65145 \\ Email : ka.nungki@gmail.com
}

Diterima : 28 Maret 2013, Direvisi : 5 April 2013, Disetujui : 12 April 2013

\begin{abstract}
ABSTRAK
Penelitian bertujuan untuk mendapatkan waktu aplikasi $\mathrm{CaCl}_{2}$, dosis $\mathrm{CaCl}_{2}$ dan aplikasi ethephon yang tepat untuk meningkatkan kualitas buah nanas. Penelitian menggunakan Rancangan Petak Petak Terbagi dengan 3 ulangan. Petak utama ialah waktu aplikasi $\mathrm{CaCl}_{2}$ yang terdiri dari 3 taraf, yaitu : 90 hari setelah pembungaan (hsp), $120 \mathrm{hsp}$ dan dua kali aplikasi pada 90 dan 120 hsp. Anak petak ialah dosis $\mathrm{CaCl}_{2}$ yang terdiri dari 3 taraf yaitu : $50 \mathrm{~kg} \mathrm{ha}^{-1}, 75 \mathrm{~kg} \mathrm{ha}^{-1}$ dan $100 \mathrm{~kg} \mathrm{ha}^{-1}$. Anak-anak petak ialah dosis ethephon yang terdiri dari 2 taraf, yaitu : $0 \mathrm{~L} \mathrm{ha}^{-1}$ dan $2,5 \mathrm{~L} \mathrm{ha}^{-1}$. Hasil penelitian menunjukkan bahwa kombinasi perlakuan waktu aplikasi $\mathrm{CaCl}_{2} 90$ hsp, dosis $\mathrm{CaCl}_{2} 50 \mathrm{~kg} \mathrm{ha}$ dan aplikasi ethephon 2,5 l ha menghasilkan distribusi tingkat kemasakan luar buah 25\% dan 50\% yang tinggi dibandingkan dengan perlakuan lain. Kombinasi perlakuan dua kali waktu aplikasi $\mathrm{CaCl}_{2}$ pada 90 dan 120 hsp dengan dosis $\mathrm{CaCl}_{2} 100 \mathrm{~kg} \mathrm{ha}{ }^{-1}$ menghasilkan kandungan Ca buah yang lebih tinggi dibandingkan perlakuan lain dan menghasilkan tekstur buah, penyakit buah, kememaran buah yang lebih rendah dibandingkan perlakuan lain. Aplikasi ethephon tidak berpengaruh terhadap kandungan $\mathrm{Ca}$ buah tetapi dapat menurunkan tekstur buah, penyakit buah serta meningkatkan kememaran buah. Aplikasi $\mathrm{CaCl}_{2}$ dan ethephon tidak berpengaruh terhadap total padatan terlarut, total asam tertitrasi dan vitmin $\mathrm{C}$ buah.
\end{abstract}

Kata kunci : $\mathrm{CaCl}_{2}$, ethephon, nanas, kualitas buah..

\section{ABSTRACT}

The objective of research was to obtain the treatment time of $\mathrm{CaCl}_{2}$ applications, dosage of $\mathrm{CaCl}_{2}$ and ethephon applications to improve the fruit quality of pineapple. This research used Split-Split Plot Design and each treatment replicated 3 times. The main plot is time of $\mathrm{CaCl}_{2}$ applications that consists of three levels, those are 90 day after flowering (daf), 120 daf and twice of $\mathrm{CaCl}_{2}$ applications at 90 and 120 daf. The sub plot is dosage of $\mathrm{CaCl}_{2}$ that consists of three levels, those are $50 \mathrm{~kg} \mathrm{ha}^{-1}, 75 \mathrm{~kg} \mathrm{ha}^{-1}$ and $100 \mathrm{~kg} \mathrm{ha}^{-1}$. The sub sub plot is dosage of ethephon that consists of two levels,

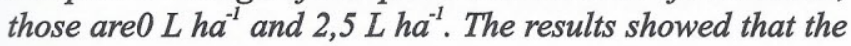

combined treatment of $\mathrm{CaCl}_{2}$ application on 90 daf, dosage of $\mathrm{CaCl}_{2} 50 \mathrm{~kg} \mathrm{ha}^{-1}$ and dosage of ethephon $2.5 \mathrm{~L} \mathrm{ha} \mathrm{H}^{-1}$ produce distribution external fruit maturity level of $25 \%$ and $50 \%$ higher than the other treatments. Combined treatment twice of $\mathrm{CaCl}_{2}$ application on 90 and 120 daf with dosage of $\mathrm{CaCl}_{2}$ $100 \mathrm{~kg} \mathrm{ha} a^{-1}$ produces calcium content higher than the other treatment and produce fruit texture, percentage of fruit diseases and percentage of fruit bruised lower than other treatments. Ethephon application had noeffect on calcium content but decreasing fruit texture, percentage of fruit diseases and improved percentage of fruit bruised. $\mathrm{CaCl}_{2}$ and ethephonapplications didnot affect the total soluble solid, total acidity and vitamin $C$. .

Keywords: $\mathrm{CaCl}_{2}$, ethephon, pineapple, fruit quality.

\section{PENDAHULUAN}

Nanas merupakan buah tropika yang memiliki nilai ekonomis tinggi. Produksi nanas mencapai $20 \%$ produksi buah tropika dunia. Pada tahun 2011, volume ekspor nanas di Indonesia mencapai 161.386 ton naik $29,48 \%$ dibandingkan tahun $2010^{(1)}$. Indonesia menempati posisi ketiga dari negara-negara penghasil nanas olahan dan nanas segar di dunia setelah Thailand dan Filipina. Salah satu produsen dan eksportir nanas kalengan terbesar di Indonesia ialah PT. Great Giant Pineapple. Sejak tahun 2004, PT. Great Giant Pineapple tercatat sebagai tiga besar produsen nanas dunia ${ }^{(2)}$. Permasalahan yang dihadapi oleh produsen nanas kaleng di Indonesia saat ini ialah kualitas buah nanas dengan tingginya tingkat kerusakan mekanis akibat kememaran buah dan kerusakan patologis yang disebabkan oleh penyakit buah. Salah satu upaya yang dapat dilakukan untuk meningkatkan kualitas buah ialah aplikasi $\mathrm{CaCl}_{2}$ dan aplikasi ethephon.

Kalsium merupakan salah satu bahan kimia yang dapat digunakan untuk mempertahankan ketegaran tekstur buah. Penggunaan kalsium baik sebelum 
maupun sesudah panen telah banyak dilakukan untuk mencegah gugurnya buah, mengurangi kerusakan sesudah panen dan mengontrol berbagai kerusakan fisiologis pada buah dan sayur. Kalsium akan mempertahankan dan memperkuat dinding sel dan selalu berada dalam bentuk $\mathrm{Ca}^{2+}$ bebas untuk mecegah kerusakan ${ }^{(3)}$. Pada salah satu bagian dinding sel buah yaitu lamela tengah merupakan daerah yang banyak mengandung pektin yang apabila berinteraksi dengan $\mathrm{Ca}^{2+}$ akan membentuk Ca pektat, yang berperan dalam menambah keterikatan antar sel. Apabila keterikatan sel terjadi dalam jumlah cukup besar maka akan terjadi jaringan molekul yang melebar dan buah menjadi kokoh padat berisi sehingga berpengaruh terhadap bobot buah $^{(4,5)}$.

Aplikasi $\mathrm{CaCl}_{2}$ dilaporkan dapat menunda kemasakan buah, sedangkan aplikasi ethephon berperan mempercepat kemasakan buah dengan seragam, serta mendapatkan buah yang masak sebelum mikroorganisme patogenik berkembang dalam buah ${ }^{(6,7)}$. Hasil penelitian Basuki et al. ${ }^{(8)}$ menunjukkan bahwa aplikasi ethephon yang dilakukan pada umur 135 hari setelah pembungaan (5 hari sebelum panen alami) dengan dosis 2,5 $1 \mathrm{ha}^{-1}$ sangat nyata menurunkan penyakit cork spot pada buah nanas.

Penelitian bertujuan untuk mendapatkan waktu aplikasi $\mathrm{CaCl}_{2}$, dosis $\mathrm{CaCl}_{2}$ dan aplikasi ethephon yang tepat untuk meningkatkan kualitas buah nanas.

\section{BAHAN DAN METODA}

\section{Bahan}

Bahan yang digunakan dalam penelitian ini ialah tanaman nanas varietas Smooth Cayenne klon GP3, $\mathrm{CaCl}_{2}$, ethephon (2-chloroethyl phosphonic acid), larutan iodium, $\mathrm{HCl}$ dan aquades. Penelitian dilaksanakan di PT Great Giant Pineapple Lampung pada bulan Januari 2013 hingga April 2013.

\section{Peralatan}

Alat yang digunakan ialah penetrometer, hand refraktometer dan boom sprayer.

\section{Metoda}

Penelitian dilakukan menggunakan Rancangan Petak Petak Terbagi (RPPT) dengan 3 ulangan. Petak utama ialah waktu aplikasi $\mathrm{CaCl}_{2}$ yang terdiri dari 3 taraf, yaitu : $90 \mathrm{hsp}$ (W90), $120 \mathrm{hsp}$ (W120) dan dua kali waktu aplikasi pada aplikasi 90 dan 120 hsp (W90+120). Anak petak ialah dosis $\mathrm{CaCl}_{2}$ yang terdiri dari 3 taraf yaitu : $50 \mathrm{~kg} \mathrm{ha}^{-1}$ (C50), $75 \mathrm{~kg} \mathrm{ha}^{-1}$ (C75) dan $100 \mathrm{~kg} \mathrm{ha}^{-1}$ (C100). Anak-anak petak ialah dosis ethephon yang terdiri dari 2 taraf, yaitu : $0 \mathrm{~L} \mathrm{ha}^{-1}(\mathrm{E} 0)$ dan 2,5 $\mathrm{L} \mathrm{ha}^{-1}(\mathrm{E} 2,5)$. Aplikasi ethephon dilakukan pada umur 150 hari setelah pembungan. Panen dilakukan pada umur 153 hari setelah pembungaan untuk perlakuan aplikasi $\mathrm{CaCl}_{2}$ dengan aplikasi ethephon, sedangkan pada perlakuan aplikasi $\mathrm{CaCl}_{2}$ tanpa aplikasi ethephon dan kontrol panen dilakukan pada umur 155 hari setelah pembungaan.

\section{Pengamatan dilakukan secara destruktifmeliputi :}

\section{Distribusi tingkat kemasakan luar buah}

Distribusi tingkat kemasakan luar buah dilakukan berdasarkan Work Instruction GGPC pada masingmasing jumlah buah setiap kemasakan $0 \%, 25 \%, 50 \%$, $75 \%$ dan $100 \%$ pada sampel 100 buah. Adapun kriteria tingkat kemasakan luar buah ialah sebagai berikut:

- $\quad 0 \%$ : semua mata buah berwarna hijau.

- $\quad 25 \%$ : mata buah berwarna kuning sempurna maksimal 25\% dari lingkar panjang (minimal satu mata buah berwarna kuning sempurna)

- $50 \%$ : mata buah kuning sempurna $>25 \%$ sampai $<75 \%$.

- $\quad 75 \%$ : mata buah kuning sempurna $75 \%$ sampai < $100 \%$.

- $100 \%$ : semua mata buah kuning sempurna.

\section{Kandungan Ca buah}

Analisis kandungan $\mathrm{Ca}$ menggunakan metode AAS (Atomic Absorption Spectrophotometer). Buah nanas sebanyak $1 \mathrm{~g}$ bobot kering diekstrak dengan HNO3 pekat, ditambah air destilata, setelah itu disaring dan diambil filtratnya. Filtrat tersebut dianalisis dengan metode $\mathrm{AAS}^{(9)}$.

\section{Tekstur buah}

Analisis tekstur buah dilakukan berdasarkan Work Instruction GGPC dengan memotong buah bagian ujung, tengah dan pangkal buah masing-masing seberat $10 \mathrm{~g}$, kemudian buah diletakkan di tempat sampel. Jarum penetrometer diturunkan selama 10 detik sehingga menembus sampel buah. Angka yang tertera pada peneterometer menunjukkan besarnya tekstur buahnanas.

\section{Kememaran buah}

Tingkat kememaran buah diamati secara visual dan dianalisis berdasarkan Work Instruction GGPC. Perhitungan persentase memar buah ialah sebagai berikut: 


$$
\text { Kememaran buah }(\%)=\frac{\text { Jumlah buah memar } \times 100 \%}{\text { Total sampel buah }}
$$

\section{Penyakit buah}

Pengamatan penyakit buah berdasarkan Work Instruction GGPC dilakukan dengan cara mengamati daging buah kemudian mengelompokkan jenis penyakit sesuai dengan gejalanya. Persentase kejadian penyakit buah nanas dihitung menggunakan rumus sebagai berikut:

$$
\mathrm{P}=\mathrm{a} / \mathrm{b} \times 100 \%
$$

$$
\text { Keterangan: } \begin{aligned}
\mathrm{P} & =\begin{array}{l}
\text { Persentase serangan penyakit } \\
\text { buahnanas }
\end{array} \\
\mathrm{a} & =\begin{array}{l}
\text { jumlah buah nanas yang } \\
\text { terserang penyakit }
\end{array} \\
\mathrm{b} & =\begin{array}{l}
\text { jumlah seluruh sampel buah } \\
\text { setiap perlakuan }
\end{array}
\end{aligned}
$$

\section{Total padatan terlarut buah (TPT)}

Daging buah nanas dihaluskan dengan blender kemudian disaring, filtrat yang telah tersaring diletakkan pada prisma hand refraktometer, skala yang terbaca menunjukkan nilai total padatan terlarut buah.

\section{Total asam tertitrasi (TAT)}

Total asam tertitrasi dianalisis berdasarkan Work Instruction GGPC dengan cara menghaluskan daging buah nanas dan diambil sebanyak $20 \mathrm{~g}$, kemudian disaring ke dalam labu takar $200 \mathrm{ml}$ lalu ditambah aquades sampai tanda tera. Bahan diambil dengan pipet filtrat sebanyak $25 \mathrm{ml}$ dan dimasukkan ke tabung erlenmeyer 100 $\mathrm{ml}$ untuk dititrasi, sebelum dititrasi ditambahkan 2 tetes indikator phenofthalein, kemudian dititrasi dengan $\mathrm{NaOH} 0,1 \mathrm{~N}$ sampai terjadi perubahan warna tepat merah jambu. Perhitungan total asam tertitrasi sebagai berikut:

$$
\text { TAT } m g / 100 \mathrm{~g} \text { bahan }(\%)=\frac{\mathrm{ml} \mathrm{NaOH} \times \mathrm{N} \times \mathrm{fp} \times \mathrm{BE} \times 100 \%}{\text { Bobot sampel }(\mathrm{mg})}
$$

\footnotetext{
Keterangan: $\mathrm{N}=$ normalitas larutan $\mathrm{NaOH} 0,1 \mathrm{~N}$

$\mathrm{fp}=$ faktor pengenceran $(100 / 25)$

$\mathrm{BE}=$ bobot ekivalen asam organik dominan dalam sampel, asam sitrat $\mathrm{BE}=64^{(10)}$
}

\section{Kandungan vitamin C}

Kandungan vitamin $\mathrm{C}$ dianalisis berdasarkan Work Instruction GGPC dengan cara menghaluskan daging buah nanas dan diambil sebanyak $20 \mathrm{~g}$ kemudian disaring. Hasil saringan dimasukkan ke dalam labu takar $200 \mathrm{ml}$ ditambah aquades sampai tanda tera. Bahan diambil dengan pipet filtrat sebanyak $25 \mathrm{ml}$ dan dimasukkan ke tabung erlenmeyer $100 \mathrm{ml}$, kemudian ditambah $2 \mathrm{ml}$ amilum $1 \%$. Larutan dititrasi dengan 0,01 $\mathrm{N}$ iodium sampai terjadi perubahan warna menjadi kehijauan. Perhitungan vitamin C ialah sebagai berikut:

$$
\text { mg Vitamin } \mathrm{c} / 100 \mathrm{~g}=\frac{\mathrm{ml} \mathrm{I}_{2} \times 0,88 \times 100}{\text { bobot sampel }(\mathrm{g})}
$$

$$
\begin{gathered}
\text { Keterangan : } \begin{aligned}
\mathrm{I}_{2} \quad & \text { larutan iodium yang digunakan } \\
& \text { untuk titrasi }
\end{aligned} \\
0,88=\text { faktor konversi dari massa molekul } \\
\quad \text { ke bobot } \\
\text { Bobot sampel = bobot sampel yang diukur }
\end{gathered}
$$

Data pengamatan yang diperoleh dianalisis dengan menggunakan analisis ragam uji $\mathrm{F}$ pada taraf nyata $5 \%$. Selanjutnya untuk mengetahui perbedaan diantara perlakuan dilakukan dengan Uji Beda Nyata Terkecil (BNT) pada taraf 5\%. Perbandingan antar perlakuan dengan kontrol dilakukan dengan uji orthogonal kontras.

\section{HASIL DAN PEMBAHASAN}

\section{Distribusi tingkat kemasakan luar buah}

Distribusi tingkat kemasakan luar buah dipengaruhi oleh adanya interaksi antara perlakuan waktu aplikasi $\mathrm{CaCl}_{2}$, dosis $\mathrm{CaCl}_{2}$ dan aplikasi ethephon. Ketiga kombinasi perlakuan tersebut menghasilkan 3 tingkat kemasakan luar buah yaitu $0 \%$, $25 \%$ dan $50 \%$. Kombinasi perlakuan waktu aplikasi $\mathrm{CaCl}_{2} 90 \mathrm{hsp}$, dosis $\mathrm{CaCl}_{2} 50 \mathrm{~kg} \mathrm{ha}^{-1}$ dan aplikasi ethephon 2,5 $1 \mathrm{ha}^{-1}$ menghasilkan distribusi tingkat kemasakan luar buah $25 \%$ dan $50 \%$ yang tinggi dan kemasakan luar buah $0 \%$ yang rendah dibandingkan kombinasi dengan perlakuan lain (Tabel 1). Pengaruh perlakuan terhadap kontrol menunjukkan bahwa tanaman yang diperlakukan aplikasi $\mathrm{CaCl}_{2}$ dan ethephon menghasilkan distribusi tingkat kemasakan luar buah $0 \%$ yang berbeda nyata dan lebih rendah dibandingkan kontrol, tetapi menghasilkan distribusi tingkat kemasakan luar buah $25 \%$ dan $50 \%$ yang berbeda nyata dan lebih tinggi dibandingkan dengan kontrol (Tabel2). 
Tabel 1. Distribusi tingkat kemasakan luar buah $0 \%$, $25 \%$ dan $50 \%$ akibat interaksi waktu aplikasi $\mathrm{CaCl}_{2}$, dosis $\mathrm{CaCl}_{2}$ dan aplikasi ethephon

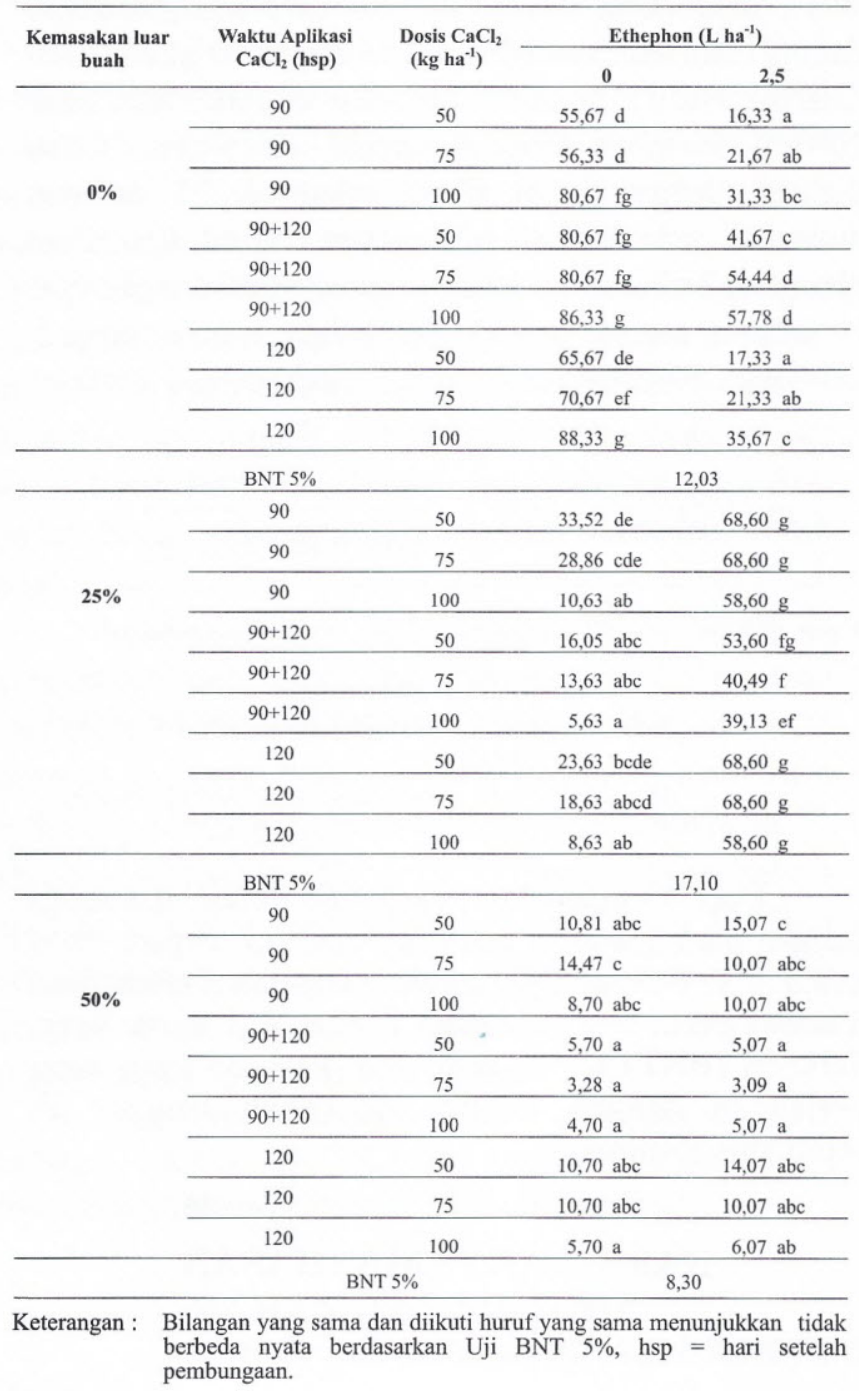

Tabel 2. Distribusi tingkat kemasakan luar buah $0 \%, 25 \%$ dan $50 \%$ pada perlakuan dan kontrol.

\begin{tabular}{cccc}
\hline \multirow{2}{*}{ Perlakuan } & \multicolumn{3}{c}{ Distribusi tingkat kemasakan luar buah } \\
\cline { 2 - 4 } & $\mathbf{0 \%}$ & $\mathbf{2 5 \%}$ & $\mathbf{5 0 \%}$ \\
\hline Kontrol & $67,67 \mathrm{~b}$ & $27,33 \mathrm{a}$ & $5,00 \mathrm{a}$ \\
\hline Perlakuan & $53,48 \mathrm{a}$ & $38,00 \mathrm{~b}$ & $8,52 \mathrm{~b}$ \\
\hline
\end{tabular}

Keterangan : Bilangan pada kolom yang sama dan diikuti huruf yang sama menunjuk kan tidak berbeda nyata berdasarkan uji orthogonal kontras.

Kalsium klorida telah dilaporkan dapat menunda kemasakan buah sehingga diperlukan aplikasi ethephon untuk mempercepat kemasakan buah dengan seragam ${ }^{(11)}$. Hal tersebut juga dibuktikan pada hasil penelitian Pujirati ${ }^{(12)}$ yang menunjukkan bahwa pemberian $\mathrm{CaCI}_{2}$ prapanen pada buah tomat dapat menyebabkan perubahan warna yang lebih lambat dibandingkan kontrol. Aplikasi ethephon pada umur 7 hari sebelum panen alami menghasilkan distribusi tingkat kemasakan luar buah nanas $50 \%$ yang lebih tinggi setelah 3 hari aplikasi ethephon dilakukan ${ }^{(13)}$.

\section{Kandungan Ca buah}

Kandungan $\mathrm{Ca}$ buah dipengaruhi oleh adanya interaksi perlakuan waktu aplikasi $\mathrm{CaCl}_{2}$ dan dosis $\mathrm{CaCl}_{2}$. Hasil penelitian menunjukkan bahwa kandungan Ca buah yang tinggi ditunjukkan pada kombinasi perlakuan dua kali waktu aplikasi $\mathrm{CaCl}_{2} 90$ dan $120 \mathrm{hsp}$ dengan dosis $\mathrm{CaCl}_{2} 100 \mathrm{~kg} \quad \mathrm{ha}^{-1}$ dan kombinasi perlakuan dua kali waktu aplikasi $\mathrm{CaCl}_{2} 90$ dan $120 \mathrm{hsp}$

Tabel 3. Kandungan $\mathrm{Ca}$ buah (mg/L) akibat interaksi perlakuan waktu aplikasi $\mathrm{CaCl}_{2}$ dan dosis $\mathrm{CaCl}_{2}$.

\begin{tabular}{cccc}
\hline \multirow{2}{*}{$\begin{array}{c}\text { Waktu Aplikasi } \mathrm{CaCl}_{2} \\
\text { (hsp) }\end{array}$} & 50 & 75 & 100 \\
\cline { 2 - 4 } & $53,23 \mathrm{a}$ & $57,19 \mathrm{ab}$ & $58,09 \mathrm{ab}$ \\
\hline 90 & $57,38 \mathrm{ab}$ & $61,36 \mathrm{bc}$ & $66,74 \mathrm{c}$ \\
\hline $90+120$ & $53,50 \mathrm{ab}$ & $57,45 \mathrm{ab}$ & $58,33 \mathrm{ab}$ \\
\hline 120 & \multicolumn{3}{c}{$\mathrm{CaCl}_{2}\left(\mathrm{~kg} \mathrm{ha}^{-1}\right)$} \\
\hline BNT 5\% & 7,59 & \\
\hline Keterangan : Bilangan pada kolom yang sama dan diikuti huruf yang sama menunjuk \\
$\begin{array}{l}\text { kan tidak berbeda nyata berdasarkan Uji BNT 5\%, hsp = hari setelah } \\
\text { pembungaan. }\end{array}$
\end{tabular}

Tabel 4. Kandungan $\mathrm{Ca}$ buah (mg/L) akibat perlakuan aplikasi ethephon dan perbandingan perlakuan dengan kontrol.

\begin{tabular}{cc}
\hline Perlakuan & Kandungan Ca buah $(\mathrm{mg} / \mathrm{L})$ \\
\hline Dosis Ethephon $\left(1\right.$ ha $\left.^{-1}\right)$ & 59,82 a \\
\hline 0 & 58,91 a \\
\hline 2,5 & 46,70 a \\
\hline Kontrol vs Perlakuan & 58,77 b \\
\hline Kontrol & \\
\hline $\begin{array}{l}\text { Perlakuan } \\
\text { Keterangan : Bilangan pada kolom yang sama dan diikuti huruf yang sama pada } \\
\text { perlakuan dosis ethephon menunjukkan tidak berbeda nyata } \\
\text { berdasarkan analisis ragam uji F pada taraf nyata } \\
\text { perbandingan kontrol dan perlakuan menunjukkan } \\
\text { berdasarkan uji orthogonal kontras. }\end{array}$ \\
berbeda nyata
\end{tabular}

Tekstur buahTekstur buah merupakan indikator dari kekerasan buah. Hasil penelitian menunjukkan bahwa tekstur buah dipengaruhi oleh interaksi antara perlakuan waktu aplikasi $\mathrm{CaCl}_{2}$ dan dosis $\mathrm{CaCl}_{2}$ baik pada bagian ujung, tengah maupun pangkal buah. Kombinasi perlakuan dua kali waktu aplikasi $\mathrm{CaCl}_{2} 90$ dan 120 hsp dengan dosis $\mathrm{CaCl}_{2} 100 \mathrm{~kg} \mathrm{ha}^{-1}$ dan kombinasi perlakuan dua kali waktu aplikasi $\mathrm{CaCl}_{2} 90$ dan 120 hsp dengan dosis $\mathrm{CaCl}_{2} 75 \mathrm{~kg} \mathrm{ha}^{-1}$ menghasilkan 
tekstur buah yang keras baik pada bagian ujung, tengah maupun pangkal buah (Tabel 5). Aplikasi ethephon berpengaruh terhadap tekstur buah dengan menurunkan tekstur bagian ujung, tengah dan pangkal buah. Hasil penelitian menunjukkan bahwa aplikasi ethephon dengan dosis $2,51 \mathrm{ha}^{-1}$ menghasilkan tekstur buah yang lebih lunak dibandingkan dengan perlakuan tanpa aplikasi ethephon, baik pada bagian ujung, tengah maupun pangkal buah. Pengaruh perlakuan terhadap kontrol menunjukkan bahwa tanaman yang diberikan perlakuan aplikasi $\mathrm{CaCl}_{2}$ dan ethephon menghasilkan tekstur buah yang berbeda nyata dan lebih keras dibandingkan kontrol(Tabel 6).

Tabel 5. Tekstur buah (mm/10 $\mathrm{g}^{\prime} 10$ detik) akibat interaksi perlakuan waktu aplikasi $\mathrm{CaCl}_{2}$ dan dosis $\mathrm{CaCl}_{2}$.

\begin{tabular}{|c|c|c|c|c|}
\hline \multirow{2}{*}{ Tekstur buah } & \multirow{2}{*}{$\begin{array}{l}\text { Waktu Aplikasi } \\
\mathrm{CaCl}_{2} \text { (hsp) }\end{array}$} & \multicolumn{3}{|c|}{ Dosis $\mathrm{CaCl}_{2}\left(\mathrm{~kg} \mathrm{ha}^{-1}\right)$} \\
\hline & & 50 & 75 & 100 \\
\hline \multirow{4}{*}{ Ujung } & 90 & $211,67 \mathrm{a}$ & $213,33 \mathrm{ab}$ & $216,67 a b$ \\
\hline & $90+120$ & $231,33 \mathrm{bc}$ & $249,33 \mathrm{~cd}$ & $252,50 \mathrm{~d}$ \\
\hline & 120 & $214,17 \mathrm{ab}$ & $228,33 \mathrm{ab}$ & $230,83 \mathrm{abc}$ \\
\hline & BNT $5 \%$ & & 16,15 & \\
\hline \multirow{4}{*}{ Tengah } & 90 & $202,50 \mathrm{a}$ & $210,00 \mathrm{ab}$ & $213,33 \mathrm{ab}$ \\
\hline & $90+120$ & $225,83 \mathrm{bc}$ & $240,83 \mathrm{~cd}$ & $251,67 \mathrm{~d}$ \\
\hline & 120 & $207,50 \mathrm{ab}$ & $214,17 \mathrm{ab}$ & $222,50 \mathrm{abc}$ \\
\hline & BNT $5 \%$ & & 23,18 & \\
\hline \multirow{4}{*}{ Pangkal } & 90 & $191,67 \mathrm{a}$ & $209,17 \mathrm{ab}$ & $222,50 \mathrm{bc}$ \\
\hline & $90+120$ & $220,83 \mathrm{bc}$ & $238,33 \mathrm{~cd}$ & $252,50 \mathrm{~d}$ \\
\hline & 120 & $205,00 \mathrm{ab}$ & $208,33 \mathrm{ab}$ & $221,67 \mathrm{bc}$ \\
\hline & BNT $5 \%$ & & 20,95 & \\
\hline
\end{tabular}

Keterangan : Bilangan pada kolom yang sama dan diikuti huruf yang sama menunjukkan tidak berbeda nyata berdasarkan Uji BNT 5\%, hsp = hari setelah pembungaan.

Tabel 6. Tekstur buah (mm/10g/10detik) akibat perlakuan aplikasi ethephon dan perbandingan perlakuan dengan kontrol.

\begin{tabular}{|c|c|c|c|}
\hline \multirow{2}{*}{ Perlakuan } & \multicolumn{3}{|c|}{ Tekstur buah (mm/10g/10detik) } \\
\hline & Ujung & Tengah & Pangkal \\
\hline \multicolumn{4}{|c|}{ Dosis Ethephon $\left(\mathrm{haa}^{-1}\right)$} \\
\hline 0 & $235,37 \mathrm{~b}$ & $230,19 \mathrm{~b}$ & $221,48 \mathrm{~b}$ \\
\hline 2,5 & $225,56 \mathrm{a}$ & 220,56 a & $216,30 \mathrm{a}$ \\
\hline \multicolumn{4}{|c|}{ Kontrol vs Perlakuan } \\
\hline Kontrol & 203,33 a & 201,67 a & 193,33 a \\
\hline Perlakuan & $230,46 \mathrm{~b}$ & $225,37 \mathrm{~b}$ & $218,89 \mathrm{~b}$ \\
\hline 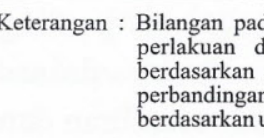 & $\begin{array}{l}\text { yang sama dan } \\
\text { ephon menunj } \\
\text { ragam uji F pa } \\
\text { dan perlakuan } \\
\text { onal kontras. }\end{array}$ & $\begin{array}{l}\text { diikuti huruf } \\
\text { kkan tidak } \\
\text { da taraf nyata } \\
\text { menunjukkan }\end{array}$ & $\begin{array}{l}\text { ang sama pada } \\
\text { berbeda nyata } \\
5 \% \text {, sedangkan } \\
\text { berbeda nyata }\end{array}$ \\
\hline
\end{tabular}

Hasil analisis korelasi menunjukkan bahwa kandungan $\mathrm{Ca}$ buah berkorelasi positif dengan tekstur buah bagian ujung $(R=0,88)$, tengah $(R=0,94)$ dan pangkal buah $(\mathrm{R}=0,95)$. Hal tersebut menunjukkan bahwa semakin tinggi kandungan $\mathrm{Ca}$ buah maka semakin keras tekstur buah. Aplikasi $\mathrm{CaCl}_{2}$ diketahui dapat mempertahankan tekstur buah karena larutan $\mathrm{CaCl}_{2}$ masuk ke dalam pori buah dan akan bekerja pada dinding sel dalam menjembatani galakturonat pada pektin. Pada salah satu bagian dinding sel buah yaitu lamela tengah, merupakan daerah yang banyak mengandung pektin yang apabila berinteraksi dengan $\mathrm{Ca}^{2+}$ akan membentuk Ca pektat, yang berperan dalam menambah keterikatan antar sel sehingga dapat mempertahankan ketegaran tekstur buah ${ }^{(14)}$.

\section{Persentase kememaran buah}

Persentase kememaran buah dipengaruhi oleh interaksi perlakuan waktu aplikasi $\mathrm{CaCl}_{2}$ dan dosis $\mathrm{CaCl}_{2}$ pada tingkat kemasakan luar buah $25 \%$ dan $50 \%$, tetapi tidak menunjukkan interaksi dan tidak berpengaruh nyata pada tingkat kemasakan luar buah $0 \%$ karena tidak terjadi kememaran buah. Pada tingkat kemasakan luar buah $25 \%$ dan $50 \%$, persentase kememaran buah yang rendah ditunjukkan pada kombinasi perlakuan dua kali waktu aplikasi $\mathrm{CaCl}_{2}$ pada 90 dan 120 hsp dengan dosis $\mathrm{CaCl}_{2} 75 \mathrm{~kg} \mathrm{ha}^{-1}$ dan kombinasi perlakuan dua kali waktu aplikasi $\mathrm{CaCl}_{2}$ pada 90 dan 120 hsp dengan dosis $\mathrm{CaCl}_{2} 100 \mathrm{~kg} \mathrm{ha}^{-1}$ (Tabel 7). Apabila ditinjau dari pengaruh perlakuan terhadap kontrol menunjukkan bahwa tanaman yang diberikan perlakuan aplikasi $\mathrm{CaCl}_{2}$ dan ethephon menghasilkan persentase kememaran buah yang berbeda nyata dan lebih rendah dibandingkan dengan kontrol baik pada tingkat kemasakan luar buah $0 \%, 25 \%$ dan $50 \%$ (Tabel 8).

Tabel 7. Persentase kememaran buah (\%) pada tingkat kemasakan luar buah $25 \%$ dan $50 \%$ akibat interaksi perlakuan waktu aplikasi $\mathrm{CaCl}_{2}$ dan dosis $\mathrm{CaCl}_{2}$.

\begin{tabular}{ccccc}
\hline \multirow{2}{*}{$\begin{array}{c}\text { Kemasakan luar } \\
\text { buah }\end{array}$} & $\begin{array}{c}\text { Waktu Aplikasi } \\
\mathbf{C a C l}_{2} \text { (hsp) }\end{array}$ & \multicolumn{3}{c}{ Dosis $\mathbf{C a C l}_{\mathbf{2}}\left(\mathbf{k g ~ h a}^{-1}\right)$} \\
\cline { 2 - 5 } & $\mathbf{2 5} \%$ & $\mathbf{5 0}$ & $\mathbf{7 5}$ & $\mathbf{1 0 0}$ \\
\cline { 2 - 5 } & 90 & $3,88 \mathrm{e}$ & $2,84 \mathrm{~d}$ & $2,27 \mathrm{~cd}$ \\
\cline { 2 - 5 } & $90+120$ & $1,80 \mathrm{bc}$ & $1,23 \mathrm{ab}$ & $0,71 \mathrm{a}$ \\
\hline \multirow{2}{*}{$\mathbf{5 0} \%$} & 120 & $3,84 \mathrm{e}$ & $2,47 \mathrm{~d}$ & $1,99 \mathrm{~cd}$ \\
\hline & BNT $5 \%$ & $3,96 \mathrm{~d}$ & $2,84 \mathrm{c}$ & $2,27 \mathrm{c}$ \\
\hline & 90 & $1,97 \mathrm{bc}$ & $1,19 \mathrm{ab}$ & $0,71 \mathrm{a}$ \\
\hline & $90+120$ & $3,95 \mathrm{~d}$ & $2,87 \mathrm{c}$ & $2,25 \mathrm{c}$ \\
\hline & 120 & \multicolumn{4}{c}{1,05} \\
\hline
\end{tabular}

Keterangan: Data hasil transformasi $\mathrm{x}=\sqrt{\mathrm{xi}+0,5}$ Bilangan pada kolom yang sama dan diikuti huruf yang sama menunjukkan tidak berbeda nyata berdasarkan Uji BNT 5\%, hsp=hari setelah pembungaan. 
Tabel 8. Persentase kememaran buah akibat perlakuan aplikasi ethephon dan perbandingan perlakuan dengan kontrol.

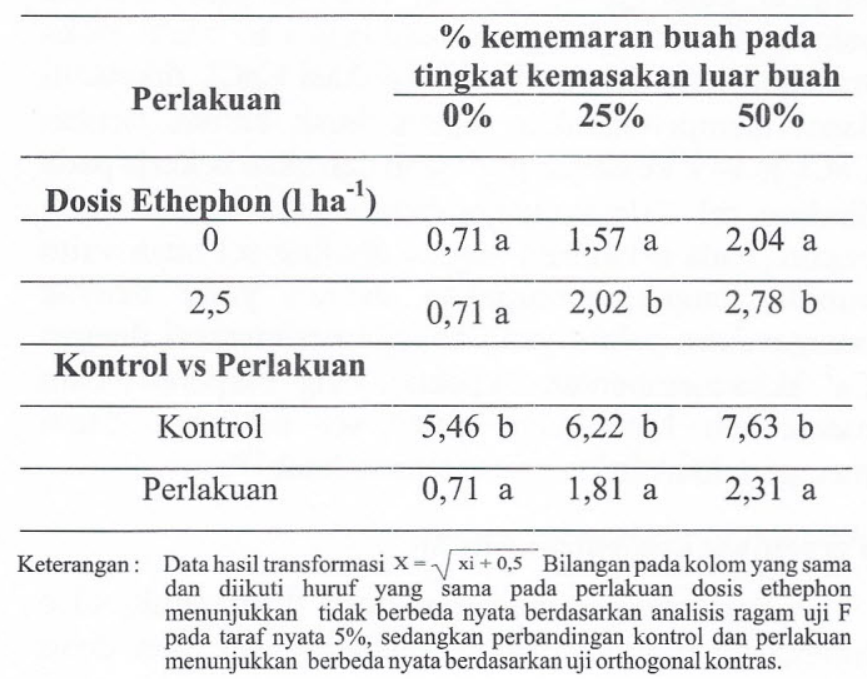

Hasil analisis korelasi menunjukkan bahwa kandungan $\mathrm{Ca}$ buah berkorelasi negatif dengan persentase kememaran buah pada tingkat kemasakan luar buah $25 \%(R=-0,84)$ dan $50 \%(R=-0,92)$. Hal tersebut menunjukkan bahwa semakin tinggi kandungan $\mathrm{Ca}$ buah maka semakin rendah persentase kememaran buah. Penggunaan kalsium baik sebelum maupun sesudah panen telah banyak dilakukan untuk mengurangi kerusakan sesudah panen dan mengontrol berbagai kerusakan fisiologis pada buah. Kalsium diketahui berfungsi untuk menghambat aktivitas enzimenzim yang menyebabkan kelunakan pada buah. Ikatan ionik kalsium pada membran sel membentuk jembatan antar komponen struktur, sehingga permeabilitas sel dapat dipertahankan ${ }^{(15)}$.

\section{Persentase penyakit buah}

Penyakit buah dipengaruhi oleh interaksi antara perlakuan waktu aplikasi $\mathrm{CaCl}_{2}$ dan dosis $\mathrm{CaCl}_{2}$ pada tingkat kemasakan luar buah $0 \%, 25 \%$ dan $50 \%$. Kombinasi perlakuan dua kali waktu aplikasi $\mathrm{CaCl}_{2}$ pada 90 dan $120 \mathrm{hsp}$ dengan dosis $\mathrm{CaCl}_{2} 75 \mathrm{~kg} \mathrm{ha}^{-1}$ dan kombinasi perlakuan dua kali waktu aplikasi $\mathrm{CaCl}_{2}$ pada 90 dan 120 hsp dengan dosis $\mathrm{CaCl}_{2} 100 \mathrm{~kg} \mathrm{ha}^{-1}$ menghasilkan persentase penyakit buah yang lebih rendah dibandingkan dengan perlakuan lain (Tabel 9). Perlakuan aplikasi ethephon menghasilkan penyakit buah lebih rendah dibandingkan perlakuan tanpa aplikasi ethephon. Pengaruh perlakuan terhadap kontrol menunjukkan bahwa tanaman yang diberikan perlakuan aplikasi $\mathrm{CaCl}_{2}$ dan ethephon menghasilkan persentase penyakit buah yang berbeda nyata dan lebih rendah dibandingkan dengan kontrol baik pada tingkat kemasakan luar buah 0\%, 25\% dan 50\% (Tabel 10).
Tabel 9. Persentase penyakit buah akibat interaksi perlakuan waktu aplikasi $\mathrm{CaCl}_{2}$ dan dosis $\mathrm{CaCl}_{2}$ pada tingkat kemasakan luar buah $0 \%, 25 \%$ dan $50 \%$.

\begin{tabular}{|c|c|c|c|c|}
\hline \multirow{2}{*}{$\begin{array}{l}\text { Kemasakan } \\
\text { luar buah }\end{array}$} & \multirow{2}{*}{$\begin{array}{l}\text { Waktu Aplikasi } \\
\mathrm{CaCl}_{2} \text { (hsp) }\end{array}$} & \multicolumn{3}{|c|}{ Dosis $\mathrm{CaCl}_{2}\left(\mathrm{~kg} \mathrm{ha}^{-1}\right)$} \\
\hline & & 50 & 75 & 100 \\
\hline \multirow{4}{*}{$0 \%$} & 90 & $2,48 \mathrm{c}$ & $2,17 b c$ & $1,82 b c$ \\
\hline & $90+120$ & $1,65 \mathrm{bc}$ & $1,32 \mathrm{ab}$ & $0,71 \mathrm{a}$ \\
\hline & 120 & $2,58 \mathrm{c}$ & $2,07 b c$ & $1,75 \mathrm{bc}$ \\
\hline & BNT 5\% & & 0,93 & \\
\hline \multirow{3}{*}{$25 \%$} & 90 & $3.95 \mathrm{~d}$ & $3,30 \mathrm{~cd}$ & $2,93 \mathrm{bcd}$ \\
\hline & $90+120$ & $2,42 b c$ & $1,78 \mathrm{ab}$ & $0,71 \mathrm{a}$ \\
\hline & 120 & $3,45 \mathrm{~cd}$ & $3,18 \mathrm{bcd}$ & 2,74 bcd \\
\hline & BNT 5\% & & 1,43 & \\
\hline \multirow{4}{*}{$50 \%$} & 90 & 5,45 ef & $5,08 \mathrm{ef}$ & $4,34 \mathrm{cde}$ \\
\hline & $90+120$ & $3,30 \mathrm{bc}$ & $2,42 a b$ & $1,93 \mathrm{a}$ \\
\hline & 120 & $5,62 \mathrm{f}$ & 4,74 def & $3,62 \mathrm{~cd}$ \\
\hline & BNT 5\% & & 1,18 & \\
\hline
\end{tabular}

Keterangan: Data hasil transformasi $x=\sqrt{x i+0,5}$ Bilangan pada kolom yang sama dan diikuti huruf yang sama menunjukkan tidak berbeda nyata berdasarkan Uji BNT $5 \%$, hsp $=$ hari setelah pembungaan

Tabel 10. Persentase penyakit buah (\%) akibat perlakuan aplikasi ethephon dan perbandingan perlakuan dengan kontrol pada tingkat kemasakan luar buah $0 \%$, $25 \%$ dan $50 \%$.

\begin{tabular}{cccc}
\hline Perlakuan & \multicolumn{3}{c}{$\begin{array}{c}\text { \% penyakit buah pada } \\
\text { tingkat kemasakan luar buah }\end{array}$} \\
\cline { 2 - 4 } & $\mathbf{0 \%}$ & $\mathbf{2 5 \%}$ & $\mathbf{5 0 \%}$ \\
\hline Dosis Ethephon $\left(\mathbf{I ~ h a ~}^{-1}\right)$ & & & \\
\hline 0 & $3,17 \mathrm{~b}$ & $4,78 \mathrm{~b}$ & $7,01 \mathrm{~b}$ \\
\hline 2,5 & $0,71 \mathrm{a}$ & $3,60 \mathrm{a}$ & $5,53 \mathrm{a}$ \\
\hline Kontrol vs Perlakuan & & & \\
\hline Kontrol & $5,37 \mathrm{~b}$ & $6,16 \mathrm{~b}$ & $7,38 \mathrm{~b}$ \\
\hline Perlakuan & $1,80 \mathrm{a}$ & $3,05 \mathrm{a}$ & $4,71 \mathrm{a}$ \\
\hline
\end{tabular}

Keterangan: Data hasil transformasi $x=\sqrt{x i+0,5}$ Bilangan pada kolom yang sama dan diikuti huruf yang sama pada perlakuan dosis ethephon menunjukkan tidak berbeda nyata berdasarkan analisis ragam uji $\mathrm{F}$ pada taraf nyata $5 \%$, sedangkan perbandingan kontrol dan perlaku
menunjukkan berbeda nyata berdasarkan uji orthogonal kontras.

Hasil analisis korelasi menunjukkan bahwa kandungan $\mathrm{Ca}$ buah berkorelasi negatif dengan persentase penyakit buah baik pada tingkat kemasakan luar buah $0 \%(R=-0,98), 25 \%(R=-0,80)$ maupun $50 \%$ $(\mathrm{R}=-0,92)$. Penambahan kalsium berperan penting dalam mempertahankan kualitas buah dalam pengaruhnya terhadap keutuhan struktur membran dan 
dinding sel. Larutan $\mathrm{CaCl}_{2}$ masuk ke dalam pori buah dan akan bekerja pada dinding sel dalam menjembatani galakturonat pada pektin sehingga ketegaran tekstur buah tetap terjaga. Tekstur buah yang keras akan membuat mikroorganisme penyebab busuk buah sulit melakukan infeksi. Kalsium juga terbukti dapat mempertahankan masuknya enzim yang dihasilkan oleh buah penyebab pelunakan buah dan enzim yang dihasilkan oleh jamur atau bakteri penyebab busuk buah atau penyakit buah ${ }^{(16)}$. Hal tersebut sesuai dengan hasil penelitian Gholamnejad dan Etebarian (17) yang menunjukkan bahwa aplikasi $\mathrm{CaCl}_{2}$ dapat menurunkan persentase penyakit buah yang disebabkan oleh Penicillium expansum pada buah apel. Aplikasi ethephon juga terbukti dapat menurunkan penyakit buah cork spot pada buah nanas ${ }^{(18)}$.

Total padatan terlarut (TPT), total asam tertitrasi (TAT) dan vitamin C

Selama proses kemasakan, buah nanas mengalami perubahan total padatan terlarut dan jumlah asam-asam pada daging buah. Hasil penelitian menunjukkan bahwa kombinasi perlakuan waktu aplikasi $\mathrm{CaCl}_{2}$, dosis $\mathrm{CaCl}_{2}$ dan aplikasi ethephon tidak menunjukkan pengaruh interaksi terhadap total padatan terlarut, total asam tertitrasi (TAT) dan vitamin $\mathrm{C}$ buah. Pada masing-masing perlakuan waktu aplikasi $\mathrm{CaCl}_{2}$, dosis $\mathrm{CaCl}_{2}$ dan aplikasi ethephon juga tidak berpengaruh terhadap total padatan terlarut, TAT dan vitamin $\mathrm{C}$ buah. Apabila ditinjau dari pengaruh perlakuan terhadap kontrol menunjukkan bahwa tanaman yang diperlakukan aplikasi $\mathrm{CaCl}_{2}$ dan ethephon menghasilkan total padatan terlarut, total asam tertitrasi dan vitamin $\mathrm{C}$ buah yang tidak berbeda nyata dengan kontrol (Tabel 11). Hal tersebut sesuai dengan hasil penelitian Bhattarai dan Gautam ${ }^{(19)}$ yang menunjukkan bahwa berbagai konsentrasi $\mathrm{CaCl}_{2}$ pada tanaman tomat menghasilkan total asam tertitrasi, total padatan terlarut (brix) dan $\mathrm{pH}$ buah yang tidak berbeda nyata. Cooke dan Randall ${ }^{(20)}$ juga menunjukkan bahwa penggunaan ethephon dalam mempercepat kemasakan buah menghasilkan pengaruh yang tidak berbeda nyata dalam hal kandungan gula dan keasaman buah nanas dengan buah masak alami tanpa menggunakan ethephon. Aplikasi ethephon juga tidak berpengaruh nyata terhadap kandungan gula tereduksi, tingkat keasaman dan kandungan vitamin $\mathrm{C}$ pada buah pir ${ }^{(21)}$.
Tabel 11. Total padatan terlarut (TPT), total asam tertitrasi (TAT) dan vitamin $\mathrm{C}$ akibat perlakuan waktu aplikasi $\mathrm{CaCl}_{2}$, dosis $\mathrm{CaCl}_{2}$, aplikasi ethephon dan perbandingan perlakuan dengan kontrol.

\begin{tabular}{|c|c|c|c|}
\hline Perlakuan & $\begin{array}{c}\text { TPT } \\
\left.\text { ( }{ }^{\circ} \text { brix }\right)\end{array}$ & TAT (\%) & $\begin{array}{l}\text { Vitamin C } \\
(\mathrm{mg} / 100 \mathrm{~g})\end{array}$ \\
\hline \multicolumn{4}{|c|}{ Waktu aplikasi $\mathrm{CaCl}_{2}$ (hsp) } \\
\hline 90 & 13,81 & 0,52 & 75,83 \\
\hline $90+120$ & 13,92 & 0,52 & 75,39 \\
\hline 120 & 13,79 & 0,52 & 75,91 \\
\hline BNT $5 \%$ & tn & tn & tn \\
\hline \multicolumn{4}{|c|}{ Dosis $\mathrm{CaCl}_{2}\left(\mathrm{~kg} \mathrm{ha}^{-1}\right)$} \\
\hline 50 & 13,81 & 0,52 & 75,08 \\
\hline 75 & 13,86 & 0,52 & 75,17 \\
\hline 100 & 13,85 & 0,53 & 75,74 \\
\hline BNT 5\% & tn & tn & tn \\
\hline \multicolumn{4}{|c|}{ Dosis Ethephon $\left(1 \mathrm{ha}^{-1}\right)$} \\
\hline 0 & 13,83 & 0,51 & 75,82 \\
\hline 2,5 & 13,86 & 0,52 & 75,52 \\
\hline BNT 5\% & tn & tn & tn \\
\hline \multicolumn{4}{|c|}{ Kontrol vs Perlakuan } \\
\hline Kontrol & 13,73 & 0,51 & 76,32 \\
\hline Perlakuan & 13,84 & 0,52 & 75,44 \\
\hline BNT 5\% & tn & tn & tn \\
\hline
\end{tabular}

Keterangan : $\mathrm{TPT}=$ total padatan terlarut, $\mathrm{TAT}=$ total asam tertitrasi, $\mathrm{tn}=$ tidak berbeda nyata, hsp $=$ hari setelah pembungaan

\section{KESIMPULAN}

Kombinasi perlakuan waktu aplikasi $\mathrm{CaCl}_{2} 90$ hsp, dosis $\mathrm{CaCl}_{2} 50 \mathrm{~kg} \mathrm{ha}^{-1}$ dan aplikasi ethephon 2,51 ha ${ }^{1}$ menghasilkan distribusi tingkat kemasakan luar buah $25 \%$ dan $50 \%$ yang tinggi dibandingkan dengan perlakuan lain. Kombinasi perlakuan dua kali waktu aplikasi $\mathrm{CaCl}_{2}$ pada 90 dan 120 hsp dengan dosis $\mathrm{CaCl}_{2}$ $100 \mathrm{~kg} \mathrm{ha}^{-1}$ menghasilkan kandungan $\mathrm{Ca}$ buah yang lebih tinggi dibandingkan perlakuan lain dan menghasilkan tekstur buah, penyakit buah, kememaran buah yang lebih rendah dibandingkan perlakuan lain. Aplikasi ethephon tidak berpengaruh terhadap kandungan $\mathrm{Ca}$ buah tetapi dapat menurunkan tekstur buah, penyakit buah serta meningkatkan kememaran buah. Aplikasi $\mathrm{CaCl}_{2}$ dan ethephon tidak berpengaruh terhadap total padatan terlarut, total asam tertitrasi dan vitmin C buah.

\section{DAFTAR PUSTAKA}

1. BPS, 2011. Horticulture statistic. http://www.bps.go.id, accessed on Dec 25, 2012. 
2. D.E. Iskandar dan H.T. Soelaeman. Raja nanas dunia, Swamajalah, 2007, pp. 21-22

3. J.M.Garcia, M.J. Ballesteros and M.A. Albi. 1995. Effect of Foliar Applications of $\mathrm{CaCl}_{2}$ on Tomato Stored at Different Temperature. Journal Agriculture Food Chemistry. 43: 9-12 (2011)

4. S.Ashari. Hortikultura Aspek Budidaya. UI Press, Jakarta, 2006, pp 635.

5. M. Mishra. Lead Acetate Induced Citotoxicity in Male Germinal Cell of Swiss Mice. Swiss, 2002, pp 291-294.

6. Mardini. Skripsi. Universitas Sriwijaya (2007)

7. N.D. Bondad. Respon of Some Tropical and Subtropical Fruit to Pre and Post Harvest Applications of Ethephon. Economic Botany 30 : 67-80(1976)

8. M. Basuki, R. Jatmika dan S. Loekito. Pengaruh Waktu Aplikasi Ripening terhadap Serangan PenyakitBuah, 2006 (unpublish).

9. Association of Official Analytical Chemists. Offical Methods of Analysis of AOAC International, 16th ed. AOAC International, Maryland, USA, 1999.

10. S.Sudarmadji. Prosedur Analisa Untuk Bahan Makanan Pertanian. Badan Penerbitan Bagian Pengolahan Hasil Pertanian, Fakultas Teknologi Pertanian, Universitas Gadjah Mada, Yogyakarta, 1976.

11. Haryati. Skripsi. Universitas Sumatera Utara (2003)

12. R. Pujiarti. Skripsi. IPB (2001)

13. E. Handayani. Pengaruh Ripening Tehadap Kualitas Buah Nanas (pH Larutan, Dosis dan
Umur Panen), 2008 (unpublish).

14. F.G. Abbott and F.R. Harker. Sensory interpretation of instrumental measurements 2: sweet and acid taste of apple fruit. Postharvest biology and technology. 24:241-250 (2003)

15. H. Izumi dan E.W Alley. Calcium Treatment to Maintain Quality of Zuchini Squash Slice. Journal Food Science. 60 (4): 789-793 (1995)

16. X.Huang. An overview of calcium's role in lychee fruit cracking. Proceeding of The $\Pi^{\text {nd }}$ International Symposium on Lychee, Longan, Rambutan, and Other Sapindaceae Plants, Belgium, 2005, pp. 231-240.

17. J.Gholamnejad and H.R. Etebarian. Effect of Calsium Chloride on The Biocontrol Efficacy of Two Antagonistic yasts against Penicillium expansum on apple fruit. Phytoparasitica. 37 (1) : 255-261 (2009)

18. I.Parnadi, G. Prijohutomo dan S. Loekito. Ripening dengan Berbagai Dosis Ethepon, 2008 (unpublish).

19. D.R. Bhattarai and D.M. Gautam. Effect of Harvesting Method and Calsium on Post Harvest Physiology of Tomato. Nepal Agriculture Research.7(1):37-41 (2006)

20. A.R. Cooke and D.I. Randa11. 2Haloethanephosphonic acids as ethylene releasing agents for theinduction of flowering in pineapples. Nature. 218: 974-975(1968)

21. W.S. Dhillon and B.V.C. Mahajan. Ethylene and Ethephon Induced Fruit Ripening in Pear, Journal of Stored Products and Postharvest Research. 2 (3) : 45-51 (2011) 